\title{
Board Characteristics and Environmental Disclosure: Evidence from
} Jordan

\author{
Ala' Mohammad Rabi \\ ${ }^{1}$ Accounting department, Faculty of Economic and Administrative Sciences, Jordan \\ Correspondence: Ala' Mohammad Rabi, Accounting department, Faculty of economic and administrative \\ sciences. Jerash private university, PO 26150, Jerash, Jordan. E-mail: rabei_83@yahoo.com
}

Received: November 28, 2018

Accepted: December 30, 2018

Online Published: January 25, 2019

doi:10.5539/ijbm.v14n2p57

URL: https://doi.org/10.5539/ijbm.v14n2p57

\begin{abstract}
This paper focuses on the relationship between the characteristics of the board of directors and the environmental disclosure in the industrial companies listed on the Amman Stock Exchange in Jordan for the period of 2014-2017. A total of 63 industrial companies were studied using three variables: the board size,board independence,board ownership, in addition to the control variable firm size.In order to achieve the objectives of the study, a measure of the level of environmental disclosure was used in the annual reports of the companies under study. The present study was based on the panel data to test the hypotheses of the study. The study found that the general trend of the level of environmental disclosure during the years (2014-2017) was increase. This is as a result of increasing awareness among Jordanian industrial companies of the importance of environmental disclosure. The level of environmental disclosure is still relatively low compared to developed countries. The study also found a positive relationship between the board size, the board ownership, the firm size and the level of environmental disclosure.
\end{abstract}

Keywords: board characteristics, board size, independent board, board ownership, environmental disclosure.

\section{Introduction}

In recent years, the negative environmental impact of economic development has become a matter of public concern in different parts of the world.After noting the many risks that have affected the environment as a result of the tremendous development in the field of industrial technological, Which ledto increased demand for environmental disclosure for companies, considering that environmental disclosure is a tool to provide environmental information to stakeholders and to reflect the environmental performance of companies and concerns about various environmental issues. Furthermore, it helps to increasing the confidence in the information provided to stakeholders and toachieving the desired environmental consensus.as well as, it helps in strengthening the competitive position of companies by adopting productive policies in line with the expectations of society and the needs of consumers to produce and use environmentally friendly products. As a result, companies become complementary to society in addressing these environmental issues (Rifai, 2012).

However,despite an increased interest in environmental disclosures in general, environmental reporting is still voluntary on an international scale. Where, there are significant differences in the quality and quantity of environmental information disclosed by companies from various industries and countries (Htay et al., 2012).

According to agency theory, the company is responsible for the decision to disclose environmental information to serve the interests of shareholders (Buniamin et al., 2011). However, Rouf (2011) argues that these reports do not usually serve the user's needs because managers are likely to think about their own interests when exercising administrative judgment, thereby increasing the disclosure gap, i.e., the difference between expected disclosure and actual disclosure. Therefore, the decision to provide or not to provide certain information is likely to depend on a variety of factors, such as the characteristics of corporate governance (Htay et al., 2012). (Sheila et al., 2012).Said et al. (2009) argued that the factors contributing to increased environmental disclosure in developing countries are the characteristics of corporate governance.

Therefore, this study focused on examiningthe relationship between the characteristics of the board of directors and the level of environmental disclosure in the Jordanian industrial companies. 


\section{Literature Review}

This section presents a literature review that dealt with the relationship between the characteristics of the board of directors and environmental disclosure, and hypotheses development.

\subsection{Environmental Disclosure}

The environmental issues and their care are modern topics. This is despite the many legislations and organizations that demand and are committed to preserving the environment. However, this is not enough unless community members realize the importance of the environment and protect it. Therefore, incumbent on society to work and contribute to changing the environmental behavior of individuals and organizations and to raise awareness of environmental problems (Ayasrah, 2018).

Darwish (2009) defined environmental disclosure as a set of information items related to the performance and activities of the environmental management of the company and its past, present, and future financial implications. Previous studies have also indicated an increase number of companies that disclose environmental information in their annual financial reports to achieve the desires of investors and other stakeholders. Therefore, this led to an increase in the content of the disclosure of environmental information from a paragraph in the annual report to the preparation of independent environmental reports published by companies on their websites or in printed paper. This disclosure takes many of the descriptive forms such as data, quantitative facts, figures, and notes about the financial statements.

Nabulsi (2011) pointed that the economic and social developments and the emergence of international markets have played an important role in increasing the importance of disclosure and expansion especially after the accounting information has become a major source of decisions for customers in these markets. In addition, it also helps the owners and other parties such as consumers, investors, consumer protection agencies, the environment, and public opinion in making decision. However, this is based on the fact that these parties have reciprocal relations with the organization, which placed accountability on the satisfaction of the needs of these parties and to meet their requirements. Hence, this forms a basis for its decision making.

Saleh (2015) stated that disclosure as a relative concept achieves many advantages for investors, creditors, project management, and other beneficiaries. It aims at rationalizing the decision making process and benefiting from the efficient use of resources, thus improving the welfare of the national economy in general. The facilities that perform their duty towards the environment leads to the development of the activities of these enterprises. In contrast, increase the pressure on companies that do not perform their duty towards the environment, which leads to reduce the activity and bears the burden of remedying damage caused by environmental pollution.

\subsection{Characteristics of the Board of Directors}

Economic collapses, financial crises in the world, and other financial problems experienced by these large companies have contributed to increasing demands for a number of ethical principles, controls, procedures, and professional practices to enhance the confidence of the users of the financial statements with information contained in the reports and financial statements they need, Particularly shareholders, investors and stakeholders (Fawzy, 2013).

The world has witnessed the liberalization of the capital markets, which resulted in an unprecedented increase in cross-border capital transfers. This led to increase size of companies, which resulted in weaknesses in the mechanisms to control the behaviors that managers, and which contributed to the occurrence of many companies in financial distress. The most important of which was the crisis of Enron WorldCom in the United States in 2001.This prompted the world to focus on corporate governance to achieve the principles of transparency and justice and to grant the right to accountability of management, to achieve Protection of shareholders and to experience the reduction of the exploitation of power granted to non-public interest (Issawi, 2013). Tahir (2011) defines corporate governance as "the system, procedures, laws, rules, regulations and decisions applicable to the management, direction, organization and monitoring of enterprises to ensure their performance so as to ensure quality and excellence in performance by selecting appropriate and effective methods to achieve plans and objectives. Suleiman (2016) pointed out that the Board of Directors, on the basis of periodic reports submitted by the executive management and the internal auditor, review the performance of the company; evaluate its work, good management practices, and the challenge of deviations and excesses; and analyzes the causes of issuing instructions to address them and to avoid their recurrence. 


\section{Hypotheses Development}

\subsection{Board Size and Environmental Disclosure}

The Jordanian Companies Law set the number of members of the Board of Directors to be, at least, five members and not more than fourteen members. Previous studies have indicated a inconsistency results about the relationship between the board size and the level of environmental disclosure (Mahmood, et al., 2018), while some studies indicate a positive relationship between the Board size and the level of environmental disclosure (Bahajar \& Al-Hajili, 2017; Mahmood et al., 2018; Trieksani \& Djajadikerta, 2016; Ienciu, 2012).

Oba \&Fodio (2012) noted that the increase board size may entail additional cost, which results in the difficulty of communication between members, and that weaker decisions are usually associated with large groups. In addition, the increase in the number of members involves a weakness in control. This is as a result of the differences of views among its members. Since there are a number of studies that indicated the absence of this relationship (Alin, et al., 2012; Htay et al, 2012).Therefore:

There is a positive correlation between the board size and the level of environmental disclosure in the industrial public shareholding companies listed on the Amman Stock Exchange.

\subsection{Board Independence and Environmental Disclosure}

The agency's theory assumes that the function of independent managers is to reduce the conflict between management and shareholders, as independent managers seen as a tool to monitor management behavior and to reduce opportunistic behavior (Fama\& Jensen, 1983). However, the presence of a high percentage of independent directors within the Board of Directors supports the ability of the Board to control, due to lack of association with the functions within the company, and the absence of material or family relationships with the executive managers this lead to achieve effective control over the actions and decisions of senior management, and to provide transparent information to external parties, and improves the level of environmental disclosure (Mahmood et al., 2018).

According to the Jordanian Corporate Governance code, the majority of the members of the board must be non-executive members and the number of independence members shall not be less than one-third of the members of the Board. Previous studies provide empirical evidence toexist positive relationship between the proportion of board independent and the level of environmental disclosure (Bajahar\& Al-Hajili, 2017;Ieniu, 2012; Oba \&Fodio, 2012; Htay et al, 2012).. On the other hand, Trieksani and Djajadikerta (2016)andMahmood, et al.(2018) stressed on the lack of relationship. Therefore:

There is a positive relationship with statistical significance between the board independence and the level of environmental disclosure in the industrial public shareholding companies listed on the Amman Stock Exchange.

\subsection{Board Ownership and Environmental Disclosure}

The low percentage of management shareholding leads to rise agency problems, because the administration will act to take actions and decisions that would increase its privileges and neglect the interests of other parties (Eng\&Mak, 2003).

Shareholders in such a situation are expected to increase oversight of management's actions to reduce agency problems. Although management oversight will be costly. Therefore, expanding environmental disclosure can be a substitute for direct control of management. The previous study (Arcay\& Vazquez, 2005; Bajahar\& Al-Hajili, 2017; Huafang\&Jianguo, 2007) has shown a positive relationship between high ownership of management and level of environmental disclosure. On other hand, Eng and Mak, (2003) found that There is no relationship between the board ownership and the level of environmental disclosure. Therefore:

There is a positive relationship with statistical significance between the board ownership and the level of environmental disclosure in the industrial public shareholding companies listed on the Amman Stock Exchange.

\section{Methodology of theStudy}

The current study is based on panel data. The study combines data of the company cross-section for a period of time series, where the data were composed of a set of special indicators 47 industrial public shareholding companies, and the period from 2014 to 2017.The data were collected from annual reports. This study is based on the data analysis in chronological form due to the increase in degrees of freedom, which leads to more accurate estimation of results (Antoniou, Guney, \&Paudyal, 2008).

\subsection{Data Collection and Population of the Study}

The population of the study consists of all the industrial public shareholding companies listed on the Amman 
Stock Exchange for the period 2014-2017, which include (63) industrial companies (Amman Stock Exchange, 2017). The sample of the study consists of all companies that meet the following conditions:

1. The shares of the company shall be traded in the financial market during the study period.

2. The company has all the necessary data to calculate the variables of the study, in addition to the availability of data for the previous year for the study period and to facilitate the calculation of some variables.

3. The company has not been incorporated or stopped trading during the study period.

4. The financial year of the company shall end on 31-12 of each year.

5. It was found that the number of companies that meet the above conditions reached 47 industrial companies.

\subsection{Measurement of Dependent Variable}

Dependent variable represents the level of environmental disclosure in the industrial companies listed on the Amman Stock Exchange. This variable was studied by content analyzing of financial statements. Content analysis is a method of research that applies methodological procedures to analyze the content of the written medium and convert it into quantitative measures (Krippendorff, 1980). This method was considered the most widely used form of data measurement in studies involving disclosures (see e.g, Gray, Kouhy\& Lavers, 1995), and has been commonly adopted in various forms in previous social and environmental studies (Guthrie \& Mathews, 1985; Guthrie\& Parker, 1990; Hackston\& Milne, 1996).

The of environmental disclosure index include twenty items (20), which have been adopted from Ayasrah (2018). Where the number (1) is given for each item in the index if was disclosed and the number (0) for each item in the indexif not disclosed for Companies. Then the number of items disclosed by the company was divided by the sum of the total items to reach the level of disclosure for each company.

\subsection{Measurement of the Independent Variable}

There are three variables for the characteristics of the Board of Directors used in this study. This is described and measured in Table 1. Annual reports provided complete information on the composition and structure of the board of directors (including the number of directors, board ownership, board independence, etc.). The size of the company was added as control variable in order to control the relationship between the independent variables and the dependent variable.

Table 1. Measurements used to measure independent variables

\begin{tabular}{llll}
\hline No & Variable Code & Variable Description & Measurement \\
\hline 1 & BSIZE & Board Size & Total number of Directors on the Board \\
2 & BOWNER & Board Ownership & $\begin{array}{l}\text { Percentage of shares owned by members of the Board of } \\
\text { Directors to the total number of shares at the end of the year }\end{array}$ \\
& BIND & Board Independence & $\begin{array}{l}\text { Percentage of independent directors to total directors } \\
\text { Total Assets }\end{array}$ \\
\hline
\end{tabular}

\subsection{Model of theStudy}

The standard model, which represents the main hypothesis of the study, was formulated as follows:

$$
D I S C=a_{1}+b_{1} B S I Z E+b_{2} B I N D+b_{3} M O W N+F S I Z E+e_{i t}
$$

\subsection{Descriptive Analysis}

The study was based on data for industrial companies for the period (2014-2017). The variables of the study model presented as follows:

Table 2. Descriptive statistics for the level of environmental disclosure (2014-2017)

\begin{tabular}{llllll}
\hline Scale (\%) & 2014 & 2015 & 2016 & 2017 & TOTAL \\
\hline mean value & 39.5 & 40.3 & 42.9 & 43.2 & 41.5 \\
Standard Deviation & 11.9 & 12.3 & 12.4 & 14.4 & 12.8 \\
Maximum Value & 60.0 & 60.0 & 60.0 & 65.0 & 65.0 \\
Minimum Value & 15.0 & 15.0 & 15.0 & 15.0 & 15.0 \\
\hline
\end{tabular}


Table 2 shows that the average level of environmental disclosure in the Jordanian industrial companies was $41.5 \%$, with a standard deviation of $12.8 \%$. The highest level of disclosure during the period was $65.0 \%$, while the lowest level of disclosure was $(15.0 \%)$. The results indicate that the level of environmental disclosure is still below the required level. The higher and lower values indicate that companies differ in the level of environmental disclosure. This may relate to internal factors related to the Company and its operations based on the level of disclosure in general. When reviewing the level of environmental disclosure during the period, the general trend was to increase it with the average level of disclosure in 2014 (39.5\%). In 2017 (43.2\%), although the increase is relatively low, it indicates an increasing awareness among Jordanian industrial companies of the importance of environmental disclosure. On the other hand, it was noted that the minimum disclosure during the years was $15.0 \%$. This is due to voluntary disclosure by companies in general based on their compliance with environmental laws and regulations, pollution control from industrial processes in general, and recycling processes adopted by companies.

Table 3 presents the descriptive statistics of the independent variables represented by the characteristics of the board of directors and the company size represented by the total assets of the companies surveyed.

Table 3. Descriptive statistics of Board characteristics and total assets

\begin{tabular}{lllll}
\hline Scale (\%) & $\begin{array}{l}\text { Board Size } \\
\text { (BSIZE) }\end{array}$ & $\begin{array}{l}\text { Board } \\
\text { (BIND) }\end{array}$ & $\begin{array}{l}\text { Independence } \\
\text { Board } \\
\text { (BOWNER) }\end{array}$ & Ownership \\
\hline mean value & 7.909 & 0.889 & 0.025 & $80,723,298$ \\
Standard Deviation & 2.266 & 0.127 & 0.082 & $21,971,830$ \\
High Value & 14.000 & 1.000 & 0.879 & $1,211,466,000$ \\
Minimum Value & 5.000 & 0.071 & 0.000 & 394,795 \\
\hline
\end{tabular}

Table 3 shows that the mean value of members of the board of directors in the industrial companies reached about 8 members. The number of members of the boards of directors of industrial companies ranged between 5 to 14 members, and this may vary according to size and need of companies based on the supreme administrative body. The average of the board independence was 0.889 , which indicates a high level of independence in the boards of industrial companies in general. The value of the standard deviation was small (0.127), indicating the convergence of the values of independence between companies. The board ownership is an average of 0.025 , indicating that the rate of board ownership is relatively low and reaches zero in many companies, with some high values of up to 0.879 . On the other hand, the mean value of the variable (total assets), which represents the company size, reached JD80.7 million. The values of the standard deviation and the maximum values indicated a significant difference between companies size in their assets, market share, and the ability of the company to provide resources.

\subsection{Test the Suitability of the Model}

Before estimating the time-scale panel data model, it is necessary to ensure that the standard models used are statistically relevant. The following table tests the existence of the multicolinearity phenomenon, where the value of the variance inflation coefficient (VIF), and the results were as follows:

Table 4. Multiple linear correlation test

\begin{tabular}{lll}
\hline Scale (\%) & Multicolinearity & \\
& VIF & Tolerance \\
\hline BSIZE & 1.213 & 0.824 \\
BIND & 1.138 & 0.879 \\
BOWN & 1.042 & 0.959 \\
SIZE & 1.192 & 0.839 \\
\hline
\end{tabular}

The VIF values indicate that the data is free from the multicolinearity problem, where all parameter values, in all independent variables, are greater than 1 and less than 5.

To determine whether the Pooled Regression model or the Fixed \& Random Effect Model was the most appropriate for the study data, the Berush-Pagan LM Test was used. In addition, to determine which model of fixed and random effects was the most appropriate, the Hausman Test was used. The results were as follows: 
Table 5. Testing the best estimated model

\begin{tabular}{lllll}
\hline $\begin{array}{l}\text { Berush-Pagan LM Test } \\
\left(\mathbf{C h i} \mathbf{2}^{2}\right)\end{array}$ & Prob. & Hausman Test $\left(\mathbf{C h i} \mathbf{~}^{\mathbf{}}\right)$ & Prob. & The result \\
\hline 170.275 & 0.000 & 2.798 & .5922 & Random effects model \\
\hline
\end{tabular}

The results of the Berusg-Pagan LM Test indicate that the regression model is not the best in the estimation of the study model. The value of the $\mathrm{Chi}^{2}$ box is significant at a level of significance less than 0.05 , indicating the suitability of the static and random effects models of the study data.

To determine which model was better, the Hausman Test was used. The value of the $\mathrm{Chi}^{2}$ box was insignificant at a significance level greater than 0.05 , indicating the suitability of the random effects models of the study data.

\subsection{Hypotheses Test}

To determine which characteristics of the board of directors (board size, board independence, board ownership) have an impact on environmental disclosure, the results of the hypothesis test are presented in the Table 6 which presents the results of the regression test random effect.

Table 6. Testing the board characteristics on the level of environmental disclosure in the industrial public shareholder companies for the years (2014-2017)

\begin{tabular}{|c|c|c|c|c|}
\hline Independent Variables & Coefficient & Std Error & T Statistics & Prob. \\
\hline Board Size (BSIZE) & 0.032 & 0.004 & 8.056 & 0.000 \\
\hline Board Independence (BIND) & 0.085 & 0.106 & 0.798 & 0.426 \\
\hline Board Ownership (BOWNER) & -0.177 & 0.062 & -2.837 & 0.005 \\
\hline Firm Size (FSIZE) & -0.010 & 0.004 & -2.936 & 0.004 \\
\hline Fixed gradient & 0.267 & 0.173 & 1.542 & 0.125 \\
\hline$R^{2}$ Selection Factor & 0.326 & & & \\
\hline Correction coefficient & 0.310 & & & \\
\hline$F$-statistic & 20.666 & & & \\
\hline $\operatorname{Prob}(F)$ & 0.000 & & & \\
\hline$D-W$ & 1.957 & & & \\
\hline
\end{tabular}

Table 6 shows the outcome of exploring the relationship between boards of directors' characteristics on environmental disclosure. The goodness of fit was accepted in a form of a significant $F$ static, and the board of directors' characteristics explained approximately 32.6 percent of the total variation in the level of environmental disclosure. With any other factors remaining constant. However, the results of the regression showed that the size of board of director had a significant impact on the level of environmental disclosure, where the regression coefficients indicated that the value of $(\mathrm{B}=0.032)$ and at a significant level $(\mathrm{Sig}=0.000)$.

Moreover, The results shows that there is no significant effect of the board independence on the level of environmental disclosure. The regression coefficients indicated that the value of $(B=0.085)$ and at a significance level $(\mathrm{Sig}=0.426)$.

The above table shows the significant effect of the board ownership on the level of environmental disclosure. Here, the regression coefficients indicated that the value of $(B=-0.177)$ and at a significant level $(\mathrm{Sig}=0.005)$.

In addition, the result shows that there is a significant effect of the company size on the level of environmental disclosure. Where,the regression coefficients indicated the value of $(\mathrm{B}=-0.010)$ at a significant level (Sig $=$ 0.004).

\section{Conclusions and Recommendations}

The results of the study showed that despite the continuous increase in the level of environmental disclosure in the industrial public shareholder companies listed on the Amman Stock Exchange and at close rates during the study period (2014-2017), the level of disclosure is still below the required limit. This may be due to the avoidance of industrial companies to disclose many aspects and areas of crisis to reduce the environmental impact of the operations of the company, especially those that affect the environment directly. The results of this study consistent with the results of the study (Bajahr \& Alhajili, 2017), which concluded that The level of voluntary disclosure in cement companies listed on the Saudi stock market is relatively low compared to 
developed countries.

Furthermore, the results showed that there is a positive relationship between the board size and the level of environmental disclosure. Where, the increase in the number of members of the board provides a variety of knowledge and expertise that reduce the problem of the agency and contribute to enhancing the capabilities of the board members. The results of this study were consistent with the results of a study (Bajahar\& Al-Hajili, 2017; Trireksani\&Djajadikerta, 2016; Mahmood et al., 2018).

Regarding to the board independence, and despite the commitment of the industrial companies to the requirements of the Jordanian Corporate Governance Guide, the results showed that there is no statistically significant relationship between the board independence and environmental disclosure in the Jordanian industrial companies. The results of this study were consistent with the results of the study (Trireksani \& Djajadikerta, 2016; Mahmoodet al., 2018). Mahmoodet al. (2018) pointed that in family-owned and family-controlled enterprise as an institution, the power of independent managers is limited. Independent managers, under family influence, lack the confidence to stand up for a different view from the rest of the board. The results also showed a positive relationship between the board ownership and the level of environmental disclosure. a low percentage of board ownership leads to a rise agency's problems. Thus, the administration may take actions, and decisions that would increase its privileges even at the expense of parties to other interests (Eng \& Mak, 2003). The study of (Arcay \& Vazquez, 2005; Bajahar\& Al-Hajili, 2017) have shown a positive relationship between high board ownership and level of environmental disclosure. As well as, The results also indicate a positive relationship between the company size and the level of environmental disclosure, as larger companies have the physical capabilities and the ability to disclose environmental information in their financial statements.

Consequently, it should be noted that this study was conducted on the industry companies listed in the Amman Stock Exchange for the period 2014-2017. Therefore, the previous studies in the field of environmental and social responsibility disclosure are still few in the Arab countries, and they need more research. Future research in this field expands the study sample and applies it to other sectors, thus facilitating the comparison of the results. This is in addition to taking into consideration other factors not included in the study model.

\section{References}

Alina, I. I., Emila, P. I., \&Maria I. N. (2012).Environmental Reporting and Good Practice of Corporate Governance: Petroleum Industry Case Study. Procedia Economics and Finance, (3), 961-967. https://doi.org/10.1016/S2212-5671(12)00258-4

Antoniou, A., Guney, Y., \& Paudyal, K. (2008). The determinants of corporate debt ownership structure: Evidence from market-based and bank-based economies, Managerial Finance, 12(34), 821-847. https://www.emeraldinsight.com/doi/10.1108/030743508

Arcay, M. R. B., \& Vazquez, M. F. M. (2005).Corporate Characteristics, Governance Rules and the Extent of Voluntary Disclosure in Spain. Advances in Accounting, (21), 299-331. https://www.sciencedirect.com/science/article/.../S08821013

Ayasrah, M. M. S. (2018). The Effect of Stakeholder pressure on the level of environmental disclosure in the industrial public shareholder companies listed in Amman stock Exchange(Unpublished Master's thesis). Jerash University, Jordan.

Bajahar, M. S.,\& al-Hajili, A. H. (2017). The impact of the Board of Directors' structure on the level of voluntary disclosure in cement companies listed on the Saudi Stock Exchange. Arab Journal of Administrative Sciences, 24(3). 383-410. search.ebscohost.com/login.aspx?...48KeUQ4Zu5\%2F5ndBqFd...

Buniamin, S., Alrazi, B., Johari, N. H., \& Rahman, N. R. (2011) Corporate Governance Practices and Environmental Reporting of Companies in Malaysia: Finding Possibilities of Double Thumbs Up. Journal Pengurusan, (32), 55-71. http://journalarticle.ukm.my/2105/1/jurus_32-06-lock.pdf

Darwish, A. M. S. (2009). The impact of accounting disclosure on the environmental performance of the Jordanian industrial companies on the rationalization of decisions and the quality of financial reports. Egyptian Journal of Business Studies - Mansoura University, 31(1).34-49.https://search.mandumah.com/Record/59871

Eng, L. L., \& Mak, Y. T. (2003). Corporate governance and voluntary disclosure, Journal of accounting and public policy, 22(4), 325-345.

Essawi, I. (2013). Development in a Changing World: A Study in the Development Concept and Indicators. Cairo: Dar Al Shorouk. 
Fama, E. F., \& Jensen, M. C. (1983).Separation of ownership and Control. Journal of Law and Economics, 2(26).301-325.https://www.jstor.org/stable/725104

Fawzy, S. (2013). Assessment of Corporate Governance in Egypt. Working Paper No. 82. Egypt the Egyptian Center for Economic Studies.

Gray, R, Kouhy, R., \& Lavers, S. (1995). Corporate social and environmental reporting: a review of the literature and a longitudinal study of UK disclosure. Accounting, Auditing \& Accountability Journal, 2(8), 47-77.

Guthrie, J., \& Mathews, M. R. (1985). Corporate Social Accounting in Australasia. Research in Corporate Social Performance and Policy, 251-277.

Guthrie, J., \& Parker, L. D. (1990). Corporate Social Disclosure Practice: A Comparative International Analysis. Advances in Public Interes t Accounting, 67-93.

Hackston, D., \& Milne, M. J. (1996). Some determinants of social and environmental disclosures in New Zealand companies. Accounting, Auditing \& Accountability Journal, 9(1), 77-108.

Htay, S. N., Rashid, H. M., Adnan, M. A., \& Meera, A. K. (2012). Impact of Corporate Governance on Social and Environmental Information Disclosure of Malaysian Listed Banks: Panel Data Analysis. Asian Journal of Finance and Accounting, 1(4), 1-24.

Huafang, X., \& Jianguo, Y. (2007). Ownership structure, board composition and corporate voluntary disclosure: Evidence from listed companies in China. Managerial Auditing Journal, 22(6), 604-619.

Ienciu, I. A. (2012). The Relationship Between Environmental Reporting and Corporate Governance Characteristics of Romanian Listed Entities.Accounting and Management Information Systems, 2(11).267-294.

Krippendorff, K. (1980). Validity in content analysis. In E. Mochmann (Ed.), Computer strategien $f \tilde{A} 1 / 4 r$ die kommunikationsanalyse (pp. 69-112). Frankfurt, Germany: Campus. Retrieved from http://repository.upenn.edu/asc_papers/291

Mahmood, Z., Kouser, R., Ali, W., Ahmad, Z., \& Salman, T.(2018) Does Corporate Governance Affect Sustainability Disclosure? A Mixed Methods Study. Sustainability, 1(10), 1-20.

Nabulsi, D. (2011). The Effect of Disclosing the Environmental Costs in the Financial Statements on the Quality of Accounting Information in the Industrial Companies in Aqaba City. Al Balqa Applied University / Aqaba University College,13-15.

Oba, V. C., \& Fodio, I. M. (2012). Board Characteristics and the Quality of Environmental Reporting in Nigeria. Journal of Accounting and Management, 2(2) 33-48.

Rifai, M. (2012). The role of measurement and accounting disclosure in raising the efficiency of environmental performance, applied study in Syrian industrial companies. (Unpublished doctoral dissertaton) University of Damascus, Syria.

Rouf, A. (2011). Corporate characteristics, governance attributes and the extent of voluntary disclosure in Bangladesh. African Journal of Business Management, 5(19), 7836-7845.

Said, R. S., Zainuddin, Y. H., \& Haron, H. (2009).The relationship between corporate social responsibility disclosure and corporate governance characteristics in Malaysian public listed companies. Social Responsibility Journal, 5(2), 212-226.

Saleh, M. M. A. (2015). The Role of the Environmental Awareness in the Application of Environmental Accounting Disclosure in the Jordanian Industrial Public Contribution Companies and Its Impact on Investor's Decisions in the Amman Financial Market.(Unpublished doctoral dissertaton), University of Jinan. Tripoli, Lebanon

Sulaiman, M. M. (2016).Corporate Governance and the Role of Board Members and Executives. Alexandria: Aldaaraljamieiat.

Tahir, A. B. H. (2011). Accounting disclosure on the environmental performance of the National Company for Cement in Libya, an exploratory study. Damascus University Journal of Economic and Legal Science, 27(1).441-459.

Trireksani, T., \& Djajadikerta, H. G. (2016). Corporate governance and environmental disclosure in the Indonesian mining industry. Australasian Account Business and Finance Journal, 10(1), 18-28. 


\section{Copyrights}

Copyright for this article is retained by the author(s), with first publication rights granted to the journal.

This is an open-access article distributed under the terms and conditions of the Creative Commons Attribution license (http://creativecommons.org/licenses/by/4.0/). 